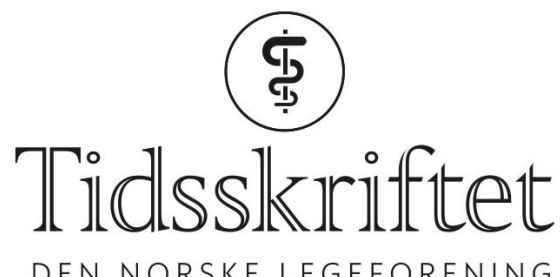

DEN NORSKE LEGEFORENING

\title{
Rettelse: Hvor mange har diabetes i Norge i 2020?
}

RETTELSE

LARS CHRISTIAN STENE

PAZ LOPEZ-DORIGA RUIZ

BJØRN OLAV ̊̊SVOLD

VERA VIK BJARK $\varnothing$

ELIN PETTERSEN SøRGJERD

INGER NJØLSTAD

LAILA ARNESDATTER HOPSTOCK

KÅRE I. BIRKELAND

HANNE L. GULSETH

Tidsskr Nor Legeforen 2020; 140: 1750-3.

I Tidsskriftet nr. 17/2020, s. 1750 skal kurvene i Figur 1 hete følgende: Den mørkeblå kurven skal hete "30-89 år», og den lyseblå kurven skal hete «Alle aldre».

Vi beklager feilen, den er rettet på nett.

Publisert: 20. november 2020. Tidsskr Nor Legeforen. DOI: 10.4045/tidsskr.20.0928

(C) Tidsskrift for Den norske legeforening 2020. Lastet ned fra tidsskriftet.no 